\title{
Geopolitical Hostage: the Case of Kaliningrad Oblast of the Russian Federation
}

\begin{abstract}
In solving the problem of preserving its sovereignty and assurances of connection with Kaliningrad, Moscow turned that Oblast into a geopolitical hostage - a territory that it received as the spoils of war in the process of cession whereby it is sought not only to maintain (the internal aspect) but also to force other countries or international institutions to carry out or abstain from carrying out any act as direct or indirect liberation of the hostage (the external aspect). Due to the specific situation of the Kaliningrad Oblast (the Potsdam train, geographical position, social-economic factors) it is the interior aspect that might be of more significance to Moscow, which is officially "covered" by the exterior one. Formally Moscow does not oppose, and even encourages that the Kaliningrad Oblast should be treated as a specific, unique region of Russia. However, in practice it does not allow this peculiarity to manifest itself. In this way it seeks to stimulate and maintain the Stockholm syndrome in the Oblast - the residents of Kaliningrad themselves must put up with the status of an ordinary Russian region.

In the article are presented concrete cases revealing how this mechanism of a Russian hostage functions in political practice: by involving the Kaliningrad exclave into the "high politics" to create the air of its peculiarity, and at the level of the "low politics, though keeping alive hopes of peculiarity in the exclave, by preventing them from being realised in practice, to tightly tie the Oblast to Russia. It is necessary to have in mind that there is no opposition between the "high" and "low" politics there.
\end{abstract}

\section{Introduction}

To express one's opinion today about the issue of Kaliningrad Oblast has become the last word in fashion both in practical international activity and in applied investigations into international relations or foreign policy. It seems that even US President George H. W. Bush knows that the Kaliningrad Oblast is on the Baltic Sea and is almost as large as the state of Maryland.

This state of affairs should not surprise anyone. The mere fact that discussions about the issues of the Kaliningrad Oblast have been held for nearly fifteen years already testifies to the fact that the Kaliningrad (in Lithuanian: Karaliaučius) Oblast is not an ordinary region of the Russian Federation. Its problems after the end of the Cold War were mainly related to the questions of what the Kaliningrad Oblast will

* Prof., dr. Raimundas Lopata - Director of the Institute of International Relations and Political Science of the University of Vilnius. Address: Vokiečiu 10, LT-01130 Vilnius, Lithuania, tel. +3705-2514130, e-mail: raimundas.lopata@tspmi.vu.lt 
become in the future, what place it will take and what role it will play. The sphere of issues to be studied was formed by the changing geopolitical environment - the exclave of Russia found itself in the way of Euro-Atlantic integration processes rapidly going on in the Baltic Sea region. Therefore, it was necessary to identify the true parameters of the Karaliaučius problem in the security, political and economic spheres.

In the early 1990's, primary main attention focused on the aspects of demilitarisation of the region and possible ways of neutralising a military threat (ranging from political-international pressure to various plans of changing the juridical status). In the middle of the 1990's, perspectives regarding the development of the region were investigated through the prism of two alternatives - the military outpost or the economic bridge between Russia and the West. At the outset of the $21^{\text {st }}$ century, studies closely related to the practical international environment of Kaliningrad appeared. As this period coincided with the beginning of the negotiations between Lithuania, Poland and the European Commission, the circle of issues under study was actually determined by the development of the European Union and its impact on Russia on the whole and on the Karaliaučius Oblast in particular ${ }^{1}$.

Overall, these stages clearly reveal the main points of that interest: the specific weight of the analysis of military-strategic threats gradually decreased and aspects of "soft" security prevailed: the social-economic backwardness of the Oblast, organised crime, illegal migration, environmental pollution, communication with the "great" Russia, etc. Moreover, the Kaliningrad was increasingly assessed not only as one of the main sources of threat to the entire region, but also as a challenge, opening qualitatively new possibilities in the development of both the Baltic Sea region and the exclave of Russia.

It is true, there were people who doubted the possibility of such a scenario. For example, the supporters of the concept of "global" confusion maintained that the analysis of Russian tendencies and trends was made more complicated not only by a geopolitical structure of the world which deteriorated after the Cold War, but also by a number of unforeseeable specific economic, social and cultural factors. These factors in the region's transformation and international adaptation are taking place in a special way ${ }^{2}$. Those who speak in terms of structural (constructive) geopolitics, explained that the vagueness of the future of the Kaliningrad Oblast was determined by incomparability of geopolitical identities - those of Russia and European Union being formed ${ }^{3}$. Despite scepticism, post-modernists who have proposed to overcome (suppress) the geopolitical differences by dialogue became prevalent in the academic and political studies of the Kaliningrad issue. According to them, the dialogue should be based on new principles of organising the political space on which EU multistage logic of management rests and which are advocated by EU development: de-terri-

\footnotetext{
${ }^{1}$ Lopata R., "Naujausios kaliningradistikos apžvalga”, Politologija, 1, 2002, p. 96 - 104.

${ }^{2}$ Radžvilas V. "Europos Sajungos plètra, JAV ir Lietuva" in Siaurès Atlanto erdve ir Lietuva. Vilnius: Eugrimas, 2001, p. 37-39; Aalto P., Structural Geopolitics in Europe: Constructing Geopolitical Subjectivity for the EU and Russia, University of Tampere, 2002.

${ }^{3}$ Aalto P. Structural Geopolitics in Europe: Constructing Geopolitical Subjectivity for the EU and Russia. Working Paper, University of Tampere, 2002. p. 26-27.
} 
toriality, decreasing importance of state borders and a qualitative change in their functions, border co-operation and international engagement seeking to eliminate differences between the neighbouring regions and to increase interdependence of the regional players ${ }^{4}$.

This paradigm became popular with the help of the "Kaliningrad Puzzle" metaphor. In Lithuania it was known as the Karaliaučius puzzle, though the authors of the metaphor ${ }^{5}$ had in mind a specific aspect of the puzzle, that is, assembly. A vague image of "a brighter future for Kaliningrad" (such is the aim of the game) corresponding to the needs and expectations of Kaliningrad residents, taking into consideration the perspective of relations between Russia and Europe, as well as aspects to the formation of the European space, should be put together in the form of solutions of the currently identified problems (specific environmental protection projects, transit of passengers and visas, border co-operation, etc.).

Nonetheless, despite intellectual advantages and certain achievements, which in practice manifest themselves in EU - Russian engagement, this game of putting together, which actually might never end, pushed aside the principal question - what role does the Kaliningrad Oblast play in the foreign and domestic policy of Russia?

\section{On the Margins of the Discussion}

The current quiet academic continuation of the debates about the uniqueness of the Kaliningrad Oblast, which formerly made a lot of noise and was held in other than an academic environment, catches the reader's attention within this context. Some scholars, let us call them particularists, explain that the geographical position of this Oblast of the Russian Federation alone turned it into a unique territorial unit demanding special attention ${ }^{6}$. The arsenal of their argument contains not only the fact of a specific geopolitical situation (Euro-Atlantic integration, challenges posed by it to the neighbouring country and its territorial political anomaly $)^{7}$, but also complications arising from identification of that territorial political anomaly (the enclave, exclave, a separate region, simply a region, etc. $\left.{ }^{8}\right)$. Generalists opposed to them, when appealing to the analogues of such territorial formation (Alaska, Danzig, Diego-Garcia, Gibraltar, Macao, West Berlin, etc.), try to remind everyone that the Kaliningrad case is not unique .

At first glance, such an exchange of opinions may remind one of firing blank cartridges. Is the definition of exclave-the territory of a state or a part thereof surrounded by the territory of other states but having a seacoast-not clear enough? Well-known is the

\footnotetext{
${ }^{4}$ Joenniemi P., Dewar S., Fairlie L.D. The Kaliningrad Puzzle. Karslkrona: The Aland Islands Peace Institute, 2000. p. 3- 4, 26.

${ }^{5}$ Ibidem.

${ }^{6}$ Krickus R.J., The Kaliningrad Question, Lanham, Boulder, New York, Oxford: Rowman and Littlefield Publishers, 2002, p. 139.

${ }^{7}$ The term made popular by G.W.S. Robinson. See: http://www.uta.edu/stillwell/notes.

${ }^{8}$ Nis S. "Kaliningrad - ne edinstvennyj anklav", Pro et Contra, 2003, t. 8, no. 1, s. 90 - 109; Holtom P., "Kaliningrad in 2001: From Periphery to Pilot Region" in Holtom P., Tassinari F. Russian Participation in Baltic Sea Region Building: A Case Study of Kaliningrad, Gdansk, Berlin, 2002, p. 53; Joenniemi P., Prawitz J., eds., Kaliningrad: The European Amber Region. Aldershot, 1998, p. 265.

${ }^{9}$ Nis S., Op. cit., p. $90-106$.
} 
axiom that every case develops within different historical contexts and differs in specific historical details. On the other hand, this specific discussion between the particularists and generalists really directs our attention to the common problems that are characteristic of territorial political anomalies and which should not be ignored, those, which have been historically verified and which a home state, the exclave/enclave, and a host state or the states surrounding the political anomaly, encounter: its administration and security, the economic situation, identity of its residents and communication with a separate territory. Home states usually seek to neutralise threats to preserve sovereignty by all possible means, establishing administration of the exclave/enclave without prejudice to the principles of political-territorial control prevailing in the home state and ensuring effective relationship-communication with it ("ignoring the host state"). The role of the host state manifests itself in its reaction to the actions of the home state seeking to ensure communication with the exclave/enclave. And the latter, especially in those cases when problems of relationship between it and the home state reach the level of so-called "high" politics, experiences the "exclave/enclave syndrome" - in the event the territorial formations are assessed as specific or extraordinary, however, specific needs of such a formation and its residents are not realised by concrete measures. Eventually such a territorial formation (and its residents) "lose" the desire to have a special status ${ }^{10}$.

Without going deeper into this discussion, it is clear that the major role in the home state - host state - territorial political anomaly triangle is played primarily by the home state through its strategy and tactics. If one remembers the question - What role does the Kaliningrad Oblast play in the foreign and domestic policy of Russia? - it should be underlined that in specific investigations dealing with the action of the home state (Russia, Moscow, the Kremlin, the federal centre) with respect to a political territorial anomaly, the motive of "non-self-determination of the home state" prevails. Some examples are provided below.

"Russia has not properly formed its real policy or attitude towards Kaliningrad yet", Sander Huisman, a visiting researcher of the European Union Institute for Security Studies, explained a year ago ${ }^{11}$.

Quite recently, in solving the issue of transit of Russian citizens from/to the Kaliningrad Oblast, Sergej Korshunov, an expert of the Committee on the International Affairs of the Council of the Russian Federation, expressed his surprise that was in line with S. Huisman: thus far Moscow has not formulated its interests with respect to the Kaliningrad Oblast, the federal centre fails to understand its geopolitical role, clear military interests, a long-term economic strategy, which would reflect the functions of the Oblast in labour division on the scale of all of Russia, in assuring foreign trade relations and measures to be used to encourage its development ${ }^{12}$.

According to Lithuanian experts, the Kremlin has several strategies with respect to Karaliaučius: the first one is that of the Oblast as a forward military post or a peculiar strategic region; the second one is as an experimental platform of economic

${ }^{10}$ Catudal H. The Exclave Problem of Western Europe. Alabama, 1979, p. 66; Holtom P. Op. cit., p. 53.

${ }^{11}$ Huisman S. A New European Union policy for Kaliningrad, Paris: The European Union Institute for Security Studies, 2002 (Occasional Paper, no. 3, p. 13).

${ }^{12}$ Korshunov S. "Kaliningrad kak problema Rosijsko-Evropejskoje partniorstva", Mezhdunarodnaja zhizn, 2003, no. 1., s. 52 - 53. 
reforms. However, even they are not absolutely clear as to which of the mentioned strategies will dominate and be realised in the policy of post-imperial Russia ${ }^{13}$. It goes without saying that Lithuanian scholars were more concerned about the place of the "host state" (Lithuania) in Russia's projections. Therefore the manner in which the above-specified problem is solved does not surprise anyone. An analysis studied how Russia sought and is seeking to make use of the issue of communication (military transit of the Russian Federation to/from the Kaliningrad Oblast through the territory of Lithuania, visas and civil transit), by striving to put a stop to the process of Lithuania's Euro-Atlantic integration and Lithuania's joining the European Union. Within this context the Lithuanians think that "taking into consideration the intensity of a diplomatic pressure exerted by Moscow on the candidate countries and the European Union, it is difficult to deny the supposition that the issue of the Kaliningrad Oblast is not a selfcontained goal, but only a measure taken by Moscow to influence the development process" 14 , to create a historical and juridical basis for encroaching upon sovereignty of the Baltic states ${ }^{15}$.

Finally, the Finn Paami Aalto, among other things has drawn attention to the attempts of the Lithuanians to explain why the Kaliningrad card found itself in the sphere of "high politics", neatly summing it up as follows: in Russia's geostrategy, Kaliningrad is a tool for Russia to carry on the tradition of the great power ${ }^{16}$.

It seems to us that this is only one facet of the home state (Moscow) and exclave (Kaliningrad) relations. In solving the problem of preserving its sovereignty and assurances of connection with Kaliningrad, Moscow turned that Oblast into a geopolitical hostage - a territory that it received as the spoils of war in the process of cession whereby it is sought not only to maintain (the internal aspect) but also to force other countries or international institutions to carry out or abstain from carrying out any act as direct or indirect liberation of the hostage (the external aspect). Due to the specific situation of the Kaliningrad Oblast (the Potsdam train, geographical position, social-economic factors) it is the interior aspect that might be of more significance to Moscow, which is officially "covered" by the exterior one. Formally Moscow does not oppose, and even encourages that the Kaliningrad Oblast should be treated as a specific, unique region of Russia. However, in practice it does not allow this peculiarity to manifest itself. In this way it seeks to stimulate and maintain the Stockholm syndrome in the Oblast - the residents of Kaliningrad themselves must put up with the status of an ordinary Russian region.

Below are presented concrete cases revealing how this mechanism of a Russian hostage functions in political practice: by involving the Kaliningrad exclave into the "high politics" to create the air of its peculiarity, and at the level of the "low politics", though keeping alive hopes of peculiarity in the exclave, by preventing them from being realised in practice, to tightly tie the Oblast to Russia. It is necessary to have in mind that there is no opposition between the "high" and "low" politics there.

\footnotetext{
${ }^{13}$ Sirutavičius V., Stanytè-Toločkienè I. Strategic Importance of the Kaliningrad Oblast of the Russian Federation, Lithuanian Annual Strategic Review 2002, Vilnius, Lithuanian Military Academy, 2003, p. p. 187.

14 Ibidem, p. 214.

${ }^{15}$ Laurinavičius Č., Lopata R., Sirutavičius V., Military Transit of the Russian Federation Through

the Territory of the Republic of Lithuania. Vilnius, 2002. p. 36.

${ }^{16}$ Aalto P. Op. cit, p. 25.
} 


\section{Karaliaučius and the "high politics": NATO Development}

Anatol Liven who visited Kaliningrad in 1991 and 1994 was perhaps the first to notice a grotesque combination of the "high" and "low" politics in the Oblast: a lot of contradictory visions of the development of the Oblast; the concerned Western offices seeking to block the path towards the destabilising security factors of the region and at the same time seeking to preserve the status quo; an enormously increased number of servicemen and the disintegrating military industrial complex; military officers of liberal views starting up private business and voting for Boris Yeltsin and the so-called reformers; alliances of conservative military officials and Russian nationalists determined to preserve Karaliaučius as the last military base in the south of the Baltic Sea and the last trophy of the Second World War (alongside the Kuril Islands); attempts to discover history, the "new Prussians" anew, to rename the town into Kantograd and to produce maximum notices possible of "Koenigsberg"; the idea of a free trade zone, which is sometimes supported by Moscow, is popular in the Oblast, however, it "does not work" in real life; and finally the hope, which is still kept alive, that the West will provide assistance to Kaliningrad just to prevent the Oblast from becoming the centre of destabilisation ${ }^{17}$.

Somewhat later, Zbigniew Brzezinski called it a reflection of geo-strategic phantasmagoria, historical and strategic confusion in post-imperial Russia where difficulties of internal transformation and failures of economic policy created a collision between the real possibilities for Russia and a still prevailing mood of the former world power ${ }^{18}$. It was this collision that naturally served as a starting point for the Karaliaučius Oblast of the Russian Federation, finding itself in a specific geopolitical position, to rapidly rise to "high politics". At first it became the object of international political futurism. Later, due its specific geographical position it became the target of practical Russian attempts to solve the said collision - to cover the inadequacy with the peculiar relations with the Western countries (Andrei Kozyrev), to limit their power by any possible means (Yevgeni Primakov), to choose the line of these strategic orientations by mutual concession (Vladimir Putin) ${ }^{19}$.

It should be noted that international political futurism with respect to Karaliaučius began to fade at the end of 1993 and the beginning of 1994 when the Minister of Foreign Affairs of Russia, Kozyrev, who was called an energetic pro-Western personality, stated that Russia "would preserve its military presence in the regions that had belonged to its sphere of interest for centuries", and the government's newspaper "Izvestija" suggested that attention should be paid to the circumstance that Russia succeeded in preserving thirty limitrophes, which formed a line from Kaliningrad to

\footnotetext{
${ }^{17}$ Lieven A., Pabaltijo revoliucija, Vilnius, 1995, p. 218 - 223.

18 Bžezinski Z., Velikaja šachmatnaja doska, Moskva: Mezhdunarodnye otnoshenya, 1999, s. 118. in Russian.

${ }^{19}$ Laurinavičius Č. "Russia's Foreign Policy after September 11", Lithuanian Annual Strategic Review 2002, Vilnius, Lithuanian Military Academy, 2003, p. 165-170.
} 
the Kuril Islands, which in essence corresponded to the territory of the former USSR. It was then that not only the issue of the instrumentality of these limitrophes to the development of the identity of post-imperial Russia, but also the question of what the attempts of the home state to preserve the stereotype of the great power within the new geopolitical context meant, was begun to be considered: is Russia waiting for a convenient moment to extend or is it getting ready to survive under the conditions of the "total siege"? 20

In the concrete Kaliningrad case, the interpretation based on the conception of the equilibrium (balancing) of power, stating that the home state uses the Oblast as a factor discouraging NATO from extending in the direction of the East, became most popular ${ }^{21}$.

Really, during the first stage of NATO development at the beginning of the1990's, Kaliningrad "found itself" on the front lines of the anti-NATO argumentation of the Russian political elite. It was not only reminded that for unification of Germany the West had promised Michail Gorbatchev that it would not extend the North Atlantic Treaty Organisation, or that such a development posed a threat to maintaining a frail democracy in Russia, but also attempts were made to issue threats of a new iron wall in which Kaliningrad embrasure would be wide open.

In some cases, Russian rhetoric reminded one of the phrase coined in the time of Nikita Khruschiov, "Berlin is the testicles of the West. When I want the West to scream, I press Berlin". As early as August 1993, Boris Yeltsin threatened Poland, which had been blessed to march to NATO, with "cold peace"; attempts were made to foist a military corridor on Lithuania, and to turn Karaliaučius into a militarystrategic bastion. The Russian Minister of Defence, Pavel Gratchiov, after visiting the Oblast in March of 1994, declared that the Oblast had become a special defence region headed by the Commanding Officer of the Baltic military navy directly subordinate to the Ministry of Defence and the General Headquarters. The generals of Russia and military analysts proposed that the military doctrine of Russia should be changed and the principle of not using nuclear weapons first should be renounced. They threatened to deploy a tactical nuclear weapon in the Oblast and constant military manoeuvres were carried out in it ${ }^{22}$. At the end of 1994 Admiral Vladimir Yegorov explained the situation in a very simple way: it is sought to preserve the territorial integrity of Russia, to bar the way of distortions in military balance, to ensure communication with Russia and the "economic stability of the Oblast". According to the Admiral, further development of the Oblast will depend on the behaviour of the neighbouring countries in maintaining bilateral security ${ }^{23}$.

\footnotetext{
${ }^{20}$ Bžezinski Z. , Op. cit., p. 130; Lopata R., Laurinavičius M. Tarptautine politika : komentarai ir interpretacijos. Vilnius, 2002, p. 252.

${ }^{21}$ Sirutavičius V., Stanytė-Toločkienė I., Op. cit., p. 176.

${ }^{22}$ Oldberg I. Kaliningrad: Russian Exclave, European Exclave. Stockholm, 2001, p. 15.

${ }^{23}$ Jegorov V., Cooperative Security in Northern Europe, Ideas on Cooperative Security in the Baltic Sea Region, Helsinki, 1995, p. 130-131.
} 
However, at the same time the military potential of the Oblast was being reduced $^{24}$, Moscow diplomats almost openly proposed to Poland and the Baltic States that they should refuse to join the North Atlantic Treaty Organisation in exchange for the demilitarisation of Karaliaučius territory ${ }^{25}$.

The first wave of NATO development was obviously not stopped and no clear limits of demilitarisation of the Kaliningrad Oblast were defined, however, in 1997 the Permanent Joint Council of NATO and Russia was established, which gave Moscow certain hopes to be drawn into the process of solving strategic issues with the $\mathrm{West}^{26}$.

On the other hand, rather heated discussions broke out in the so-called security community of the West about the actual military-strategic significance of Kaliningrad.

It has been considered until now the motivations of the analysts and practitioners of international security who derisively assessed the idea of "Kaliningrad - the advanced post" and experts who treated it "very seriously". It is still remembered how the US Deputy State Secretary Richard Holbrook never forgot to underline that the issue of the Kaliningrad Oblast seemed complicated only when it was looked at through the geographer's eyes, though in fact it was a part of Western - Russian relations. The conclusion drawn by the famous RAND Corporation analysts, Ronald D. Asmus and Robert C. Niurick, is that the Karaliaučius Oblast is a strategic military advanced post, a concentration of Russia's huge military power, which turns the Baltic states into a special case ${ }^{27}$. Then both opinions were received sensitively in the Baltic States and especially in Lithuania because it seemed that at that time it had not been decided yet whether the special case was an advantage, or on the contrary, a disadvantage. However, within the context of experimental considerations, the resolution of the US Republican Christopher Cox was met especially favourably, which in essence offered American economic assistance to Russian Kaliningrad in exchange for demilitarisation the region ${ }^{28}$.

Irrespective of Lithuanian assessments, in the international security discourse the Kaliningrad factor officially came to be assessed as a problem of relations between the West (NATO) and Russia, though obviously this region of the Russian Federation began to fulfil sooner the function of a pledged thing than that of retention in the strategic East - West exchange based on the tactics of retention - appeasement. By the way, within this context the intervention of some deputies of the Duma of the Kaliningrad Oblast in October 1997, seeking to relate the Lithuanian-Russian Treaty on the issues of the state border being signed to the issue of Russian military transit through the territory of Lithuania to/from the Kaliningrad Oblast, seemed especially expressive $^{29}$.

${ }^{24}$ From 1993 to 1998 the number of military helicopters decreased from 48 to 42, the number of fighter planes - from 35 to 28 , that of submarines - from 15 to 2, that of frigates - from 24 to 4 , the number of patrolling border vessels - 140 to 30. During that period only the number of tanks increased from 620 to 1000 . For more detail about it see: Sirutavičius V., Stanytė-Toločkienė I., Op. cit., p. 177. It should be noted that such an increase was in essence related to a lack of financial means to take them to "great Russia".

${ }^{25}$ Landsbergis V. Karaliaučius ir Lietuva, Vilnius, 2003, p. 132; Krickus R.J., Op. cit., p. 72.

${ }^{26}$ Lopata R., Vitkus G. sud., NATO: vakar, šiandien, rytoj. - Vilnius, 1999, p. 75.

${ }^{27}$ Laurinavičius Č., Lopata R., Sirutavičius V. , Op. cit., p. 47-49; Krickus R.J., Op. cit., p. 56.

${ }^{28}$ Landsbergis V., Op. cit., p. 136-139.

${ }^{29}$ Krickus R.J., Op. cit., p. 63. 
The situation repeated itself in the debates about the second wave of NATO development and its practical distribution. Making use of the events in Kosovo, in 1999 Moscow made traditional anti-NATO rhetoric stricter, "froze" its participation in the NATO - Russian Permanent Joint Council, began to speed up the plans cherished since 1996 to establish a Russian - Belarussian union state, and organised grandiose joint Russian-Belarussian military manoeuvres "Zapad-99" in the Kaliningrad Oblast to prove the revived balancing. The mission of de-escalation was rehearsed during the manoeuvres imitating the use of a tactical nuclear weapon to repel NATO aggression.

In July 2000 Vladimir Putin arrived in Baltijsk to celebrate Navy Day and openly spoke about re-militarisation of that limitrophe, underlining that special attention would be focused on the Russian fleet in the Baltic Sea taking into consideration Russia's strategic interests in all the seas and oceans ${ }^{30}$. It was not only the entire package of documents adopted in the Kremlin on national security, foreign policy, military doctrine and military reforms, but also the meeting of the College of the Federal Security Council held in November 2000 and given the high-sounding name of "On the Situation and Measures to Resist Threats Posed to Security and Sovereignty of the Russian Federation in the Kaliningrad Oblast", that demonstrated that the President's words were not just empty rhetoric ${ }^{31}$.

As if confirming Moscow's turn towards reviving Karaliaučius in the role of a military advanced post, at the beginning of 2001 statements appeared stating that apparently Russia, in carrying out its threat to resist the new NATO enlargement toward the East by all possible means, deployed a tactical nuclear weapon in that territory ${ }^{32}$. At the same time, rumours spread about a possible deal between Germany and Russia at the expense of Karaliaučius, and in the spring of 2001 real pressure exerted by Moscow to legalise Russia's military transit through the territory of Lithuania to/from the Kaliningrad Oblast by a political treaty came to light. Prior to a visit of the President of the Republic of Lithuania, Valdas Adamkus, to the Russian Federation at the end of March, this pressure reached a climax and turned into antiLithuanian hysterics, incidentally, accompanied by rumours spread that the Russians would offer nearly half of the Kaliningrad Oblast in exchange for Lithuania's refusal to join NATO or would not allow President Valdas Adamkus to visit the Kaliningrad Oblast ${ }^{33}$

Though during the visit it was possible to perceive that, after Lithuania had resisted pressure with help from the outside, Russia's authorities tended to put up with membership of the Baltic States in the Alliance ${ }^{34}$, supporters of the hard line

\footnotetext{
${ }^{30}$ Oldberg I., Op. cit., p. 16.

${ }^{31}$ Lopata R. "Relations with the Kaliningrad Oblast within the Context of Euro-Atlantic Integration. Report made at the meeting of the Foreign Policy Council of Lithuania”, Vilnius, 2001, December 21, p. 2. - in Lithuanian

${ }^{32}$ Lopata R., Laurinavičius M. Op. cit., p. 222-224.

${ }^{33}$ Laurinavičius Č., Op. cit., p. 164; Lopata R., Laurinavičius M., Op. cit., p. 236.

${ }^{34}$ Laurinavičius Č., Op. cit., p. 164.
} 
with the West, the so-called "hawks", went on expressing their dissatisfaction. The number of statements made in Moscow, which related NATO development to the extension of the Conventional Armament Restriction Treaty in the eastern part of the Baltic States and Russia's participation in an anti-terrorist coalition increased and Vladimir Valujev, Commanding Officer of the Navy recently appointed in Kaliningrad, even threatened that he would not need a nuclear weapon to "put something in its right place" because there are 47 nuclear power stations around Oblast, which are vulnerable to conventional armaments ${ }^{35}$. The former Commanding Officer of the fleet, the present Governor of the Kaliningrad, Oblast V. Jegorov, as well as some deputies of the Duma of the Oblast together with its Chairman Vladimir Nikitin at the head, who, by the way, had explained before and after meetings with the President of the Country that NATO development did not pose any threat to the region, found themselves in a very inconvenient situation. The highest officials of the Oblast started to insist on postponing ratification of the Agreement on the Russian-Lithuanian Border $^{36}$.

It is true, this did not change the essence of the matter. With the second wave of NATO development moving forwards, on 27 May 2002 a joint NATO and Russian Council was founded. Though Russia was not granted a veto right in solving the issues of the development of the Alliance or the security of its members, Moscow could boast of sitting together with the representatives of the NATO states in accordance with the so-called "formula of 20". It looks as if the Kremlin once again clearly demonstrated within the context of retention - appeasement that it treated Kaliningrad as a hostage.

\section{Kaliningrad and the "Low Politcs": the free (extraordinary) economic zone}

Once during a visit to Kaliningrad I happened to hear the following remark made by an influential local politician: "Today the Kaliningrad Oblast of the Russian Federation is a beautiful but blind girlie". At the time, we did not argue about the beauty because another allegory was offered - a fairy tale about Sleeping Beauty. The implied sense was easily perceived -it is easier to wake up a sleeping person than to expect the blind to recover his sight. It seems that we, Lithuanians and Russians, did not understand one another then. It seemed to us that residents of Kaliningrad in essence ignored all efforts made by Lithuania and the West on the whole to wake them up, that is, to encourage them to think that the future of the Oblast depended on their local efforts. We failed to understand that these efforts were being made, let alone the question of why they were ruined.

Today it is not concealed that the tone for the "low politics" was set by the considerations that started as early as 1989 between Kaliningrad and Moscow about the possibilities for the Oblast to function after Lithuania's succession from the USSR.

\footnotetext{
35 "Vsegda gotovy", Itogi, 2001 May 30, no 20 (258), http://Itogi.ru.

${ }^{36}$ Lopata R., Laurinavičius M., Op. cit., p. 231.
} 
It was then that the region was given hopes that its lifebuoy was a raising of status (to that of a republic within the structure of the Russian Federation ${ }^{37}$ ) and pluralism in economic development. A working group headed by the Prime Minister of the Russian Federation V. Vorotnikov did not consider the issue of the status of the Oblast. Moscow was getting ready to block the path towards the idea of "sovereignisation" that was gaining popularity in the then USSR by means of a new conception of regional policy - regional self-sustainability. The latter, by the way, called for both free enterprise and a free economic zone, was attractive to the majority of the then leaders of the regions because it provided for not only their greater independence in solving economic issues, participation of foreign capital in establishing joint enterprises, but also handing over to them management of the objects subordinate to the Union. In July 1990 - September 1991, the Supreme Council of the Russian Federation approved the status of a special economic zone for eleven regions of Russia (7\% of the territory with $13 \%$ of the Russian population). At the end of the year about 150 more regions expressed a desire to obtain such a status. However, at the end of 1991 and the beginning of 1992, when Moscow decided to implement the concept of an "open economy", the new aspirants were struck off the list and a rather fierce competitive fight broke out among the old ones.

It was during that period that the Mayor of St Petersburg, Anatolij Sobchak, succeeded in persuading the Kremlin not to increase military forces in Leningrad region at the expense of the soviet troops being withdrawn from Central Europe ${ }^{38}$, suggesting that they, the naval forces in particular, should be deployed in the Kaliningrad Oblast. The Federal Centre, as if justifying itself, went on adopting legal acts explaining the Ordinance "On the Economic-legal Status of the Free Economic Zone "Jantar" in the Kaliningrad Oblast" of the Prime Minister of the Supreme Council of the Russian Federation of June 3, 1991. On September 25, 1991, the Council of Ministers of the Russian Federation approved the "Memorandum on the Free Economic Zone (FEZ) "Jantar", and in December 1992, the President of the Russian Federation issued the Order "On Assurance of External Economic Conditions for the Development of the Kaliningrad Oblast". These acts recorded those exemptions and investments to be allocated to the development of infrastructure and agriculture, which were thought to enhance the economic development of the region, and politically - to accentuate the exceptionality of the region. Incidentally, at the end of 1992 the State Duma of Russia agreed to consider the law that had been drawn up in Kaliningrad ${ }^{39}$, and the then Governor of the Oblast Jurij Matochkin even spoke about the possibility for Kaliningrad to become the Baltic Honk Kong within a period of ten years.

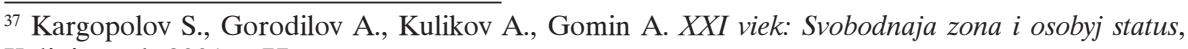
Kaliningrad, 2001, s.77.

${ }^{38}$ Krickus R.J. Op. cit., p. 58.

${ }^{39}$ Clopeckij A., Fiodorov G. Kaliningradskaja oblast: region sotrudnichestva, Kaliningrad, 2000, s. 331.
} 
However, on 2 July 1993, after the federal law "On Customs Tariffs", which annulled the exemptions, was adopted, the validity of the free economic zone in Karaliaučius Oblast was terminated. Though at the end of 1993 the edict of the President of Russia “On the Kaliningrad Oblast”, in May 1994 the Ordinance of the Government "On Urgent Measures to Stabilise the Economic Condition in the Kaliningrad Oblast", and on 12 October 1994 the Resolution of the Russian Security Council "On the Development of the Free Economic Zone in the Kaliningrad Oblast" were issued, in essence, the free economic zone did not function. The new edict of the President of March 6, 1995 on the annulment of exemptions to be applied to the free economic zone "Jantar" was only a formality. The draft law "On Raising the Status of the Kaliningrad Oblast" submitted to the State Duma of Russia in 1994, turned into the law "On Strengthening Sovereignty of the Russian Federation on the Territory of the Kaliningrad Oblast", the customs procedures were made stricter, border control was strengthened, and trade agreements concluded between the region and other countries, were annulled. The Deputy Prime Minister of Russia Sergej Shachraj, who visited Karaliaučius shortly after the visit of the Defence Minister P. Gračiovo, openly attacked "local separatists supporting Western expansion", and stated that the future of the Oblast, first and foremost, would be decided by the strategic interests of the entire country ${ }^{40}$.

According to the residents of Kaliningrad themselves, at the end of 1995 a frail political balance between the interests of Oblast and Moscow was somehow legalised by the federal law "On the Extraordinary Economic Zone in the Kaliningrad Oblast" which was approved by the Federal Council on January 5, 1996, and signed on January $22^{\text {nd }}$ by Boris Yeltsin ${ }^{41}$. On that occasion the Prime Minister of the Russian Federation Vladimir Shumeiko even mentioned the power of Region autonomy, expressed hope that the Oblast might become the centre of international congresses, a visa-free tourist zone and, on the whole, an "experiment of liberal economy". However, the federal law did not give the anticipated result. The "Agreement between the Kaliningrad Oblast and the Russian Federation" signed and the "Agreement between the Government of the Russian Federation and the Administration of the Kaliningrad Oblast on Division of Competencies" made at the beginning of 1996, as it turned out later, granted no special rights to the Oblast ${ }^{42}$. Though on September 29, 1997, the "Federal Target Program for the Development of the Extraordinary Economic Zone in the Kaliningrad Oblast for 1998 - 2005" was announced, the Duma of the Oblast passed the Law "On Local Free Economic Zones in the Kaliningrad Oblast", and in May 1998, adopted the "Regional Program for the Social Economic Development of the Kaliningrad Oblast", privileges that were made stricter were only illusions. There was nothing left to do for the then Administration of the Oblast with Governor Leonid Gorbenko at the head but appeal to the Gibraltar example and console itself hoping that in the future it would be possible to co-ordinate functions of the advanced post and the experimental platform of economic reforms ${ }^{43}$.

${ }^{40}$ Oldberg I. Op. cit., p. 55.

${ }^{41}$ Gorodilov A., Kozlov S. Geopolitika, Kaliningrad, 2003, s. 61.

${ }^{42}$ Clopeckij A., Fiodorov G., Op. cit., s. 337.

${ }^{43}$ Oldberg I. Op. cit., p. 18; Clopeckij A., Fiodorov G. Op. cit., s. $364-368$. 
Today there are lots of explanations why the fate of the free, and later the extraordinary, economic zone was determined by a contradictory process of Russia's federalisation, the conceptions of regional policy and the abundance of legal interventions (during the period between 1992 and 1996 more than ten legal acts and secondary legislation often contradicting one another were passed) regulating the activity of such zones caused by a lack of corresponding financial resources from Moscow, a complicated social-economic situation in the Russian Federation shaken by various crises (for example, the 1998 so-called financial crisis), poor administrative abilities of the political elite of the Kaliningrad Oblast, a high level of corruption, inertness of the public, etc. ${ }^{44}$ All of this explains the fate of the free (extraordinary) economic zone in Kaliningrad Oblast quite satisfactorily. At the same time, however, some other circumstances cannot be ignored.

Having more closely familiarised oneself with the acts regulating the activity of the free (extraordinary) economic zone, or programs aimed at their implementation, it becomes obvious that the aspiration to consolidate Russia's sovereignty in the Oblast and make use of the territory of the Oblast ensuring the defensive power of the country were declared to be the major political priority worth financing. In practice this meant that that the greatest part of the funds provided for in various programs came as subsidies to maintain the military-industrial complex ${ }^{45}$. On the other hand, in assessment made by the residents of Kaliningrad themselves, despite a legal change in the base of the free (extraordinary) economic zone, complications and paralysis caused by it, and one-sidedness of the financing priority, the idea of the free (extraordinary) economic zone nonetheless encouraged structural changes in the economy of the Oblast, played a positive role in stimulating the establishment of joint capital enterprises, and became the idea politically unifying the public ${ }^{46}$ and formed the basis for harmonising the interests of the Oblast with those of the federal centre ${ }^{47}$.

The residents of Kaliningrad explained that the problem laid in the fact that Moscow by "presenting one or another decree with one hand, usually took it back with the other hand". In other words, the federal centre, while raising hopes of granting the Kaliningrad Oblast special status, demanded that all the actions should be co-ordinated with it. This, in turn, increased tension and mistrust between the Oblast and the centre and eventually made it confess that the "peculiarity of the Oblast manifested itself in its closeness" and the term "zone" had to be understood in the most primitive sense of the word ${ }^{48}$.

\footnotetext{
${ }_{44}$ Sirutavičius V., Stanytė-Toločkienė I., Op. cit., p. 176.

${ }^{45}$ Kargopolov S., Gorodilov A., Kulikov A., Gomin A. Op. cit., s. 67; Clopeckij A., Fiodorov G. Op. cit., s. 41.

${ }^{46}$ Kargopolov S., Gorodilov A., Kulikov A., Gomin A. Op. cit., s. 9.

${ }^{47}$ Gorodilov A., Kozlov S., Op. cit., s. 61.

${ }^{48}$ Kargopolov S., Gorodilov A., Kulikov A., Gomin A., Op. cit., s. 9, 138.
} 


\section{EU Development and Kaliningrad: combination of "high" - "low" politics}

EU development towards the East made the Kaliningrad Oblast's role as Moscow's hostage more apparent. This was primarily due to Moscow's manipulations of the Oblast, in practical policy by supporting tendencies of both its possible "opening" and its possible further "isolation". The neighbouring countries, Poland and Lithuania, which were preparing to accede to the European Union as well as the European Commission, were also drawn in that game.

Today it is universally recognised in essence that desperate attempts, made particularly by Vilnius, to promote the idea that the Kaliningrad Oblast of the Russian Federation deserves special attention, which would allow the region to be turned into an example of the development of relations between the West and the East. These efforts contributed greatly to putting the Kaliningrad issue on the agenda of Russia and the European Union. Of course, in seeking to realise its national interests, Vilnius offered a highly rational principle of co-operation - to turn problems into advantages. Lithuania's attempts met with a positive Russian reaction. As far back as 1998, Moscow did not oppose putting the Kaliningrad Oblast on the agenda of the Council of the Baltic Sea States and including it in the initiative of the EU North dimension. It was not only institutionalisation of regional co-operation but also joint Vilnius - Moscow proposals significant to EU development, which have acquired the international name of the "Nida initiative", which demonstrated that residents of Kaliningrad also positively assessed Lithuania's attempts to "open" Kaliningrad. So much so that in October 1999 the Prime Minister of Russia, Vladimir Putin, personally expressed his opinion on the situation being formed, announcing the possibility of transforming the Oblast into a "pilot" experimental region in the relations with the EU, and also to sign a special EU agreement ensuring protection of the Oblast as the subject of interests of the Russian Federation ${ }^{49}$.

Though the idea of the "pilot region" was not developed, it was then that great excitement was felt in Kaliningrad because it was thought that this idea would again open the way to giving a special status to the Oblast. At the end of 1999 and the beginning of 2000, Moscow did not stifle these expectations. However, it was eventually done in a really peculiar way - by increasing political tension in the Oblast.

First a barrage of criticism against the Governor of the Oblast, L. Gorbenko, filled the broadcasts of Russian Independent Television. Then it appeared in the articles published in the central and local press: reasoned accusations of corruption, relations with the criminal world, encouragement of smuggling, criminal rampages of the "Governor's family" itself. High officials who arrived from Moscow (for example, Vice Minister of Foreign Affairs Igor Ivanov) openly expressed dissatisfaction not only with "regional autarchy" but also with the fact that the Governor could not give a concrete answer to the following question: what plans is the Administration of the Oblast devising with respect to the EU Northern dimension and how is it getting ready to become a "pilot region" ${ }^{50}$ ?

${ }^{49}$ Sirutavičius V., Stanyte-Toločkienė I. Op. cit., p. 135, Kargopolov S., Gorodilov A., Kulikov A., Gomin A. Op. cit., s. 134 - 135; Lopata R., Laurinavičius M. Op. cit., p. 217, 221.

${ }^{50}$ Lopata R., Laurinavičius M., Op. cit., p. 167. 
At the same time, information that the law on the territorial status of Kaliningrad was being drawn up in Moscow appeared in the newspapers. It was again planned to formally approve the existence of the extraordinary economic zone in the Oblast and at the same time to introduce direct federal governing. And this meant that the Governor would not be elected, the Kremlin would appoint him/her. Rumours also spread that the possible successor would be the retired rear admiral, the First Vice-Governor of St Petersburg, Vladimir Grishanov ${ }^{51}$. Hence, a seaman, like L. Gorbenko.

L. Gorbenko himself elucidated the situation following meetings in the Kremlin. Moscow was considering the territorial-administrative reform of Russia, which would divide the territory of the country into seven federal districts, Kaliningrad would be attributed to the Central one, and the election of the Governor would be held at a planned time - in autumn of the year 2000.

It is known that President Vladimir Putin issued an order concerning the territorial administrative reform in May. On the eve of the reform, news programmes on Russian Television showed a future "political" map of the country. Karaliaučius Oblast had been coloured in the same colour as the Central federal district on the map. The colours changed after the order had been issued - the Oblast was now assigned to the north-western district.

The election of the Governor was held at the planned time - in October and November, 2000. Two essential things distinguished programs of the old and new aspirant, Admiral V. Jegorov. Valdimir Putin openly regarded V. Jegorov with favour. V. Jegorov urged harmonising of the legal basis of the Oblast (and the country) with that of the EU. V.Jegorov won the election ${ }^{52}$.

The Admiral's victory again raised hopes in Kaliningrad that the Oblast would be given special attention. Both external and internal facts allegedly testified to that.

In November 2000 the strategic document of EU development specified officially for the first time that Kaliningrad would feel a considerable impact from EU development. In January 2001 appeared the Communiqué of the European Commission, "EU and Kaliningrad", in which it was underlined that due to the unique geographical position of the Oblast, the impact on of EU development on the Oblast might be greater than had been thought. In February, the EU Commissar for external affairs, Chris Patten, and the Minister of Foreign Affairs of Sweden, Anna Lindh, and in March - the President of the Republic of Lithuania, Valdas Adamkus, visited the Oblast. On the whole, during the first six months after the election of the Governor, delegations from nearly all the European Union states visited the Oblast and the Governor himself often was a member of Russian official delegations to the EU states.

In Moscow, V. Jegorov easily resolved the conflict caused by the decision taken by the Trade Committee of Russia which revoked privileges of the extraordinary economic zone. He received a promise from the President and the Prime Minister M. Kasjanov, that Moscow would reconsider the decision on attributing the Oblast to

\footnotetext{
${ }^{51}$ Ibidem, p. 166-167.

${ }^{52}$ Ibidem., p. 217. An interesting detail - following the election L. Gorbenko receive a personal gift from the President bearing the following inscription "For achievements in developing economy of the Kaliningrad Oblast"
} 
the federal district, perhaps giving it the status of the eighth federal district. Some Vice Governors of the region would be included into a working group responsible for the study of the consequences of EU development for Russia, and politicians of Kaliningrad would be given a special role in preparing a special agreement between Russia and the EU on the Kaliningrad Oblast ${ }^{53}$.

\subsection{However, the promises gradually started to be repudiated.}

When on March 22, 2001 the Government of Russia considered the plans for ensuring the social-economic development and vitality of the Kaliningrad Oblast, M. Kasyanov openly, like Shumeiko in 1996, declared that the region would become "the example of application of the market methods" ${ }^{4}$. Actually the plan provided for only those measures which would help Moscow extend the boundaries of its competence ${ }^{55}$.

At the meeting of the Security Council of the Russian Federation held on July $26^{\text {th }}$, Vladimir Putin urged turning the factors of EU development that were negative for Kaliningrad into positive ones as soon as possible and to more quickly make a decision concerning the "Federal Target Program for the Social-economic Development of the Kaliningrad Oblast for 2002 - 2010" prepared by German Gref. The program, lacking nearly $50 \%$ of financing funds, was approved only in December. During the meeting it was decided to establish the position of the Deputy of the President's Commissioner in the northwestern federal district, Viktor Tcherkesov. Andrej Stepanov was appointed Deputy responsible for co-ordinating the activities of federal institutions in Kaliningrad and he had to ensure Moscow's influence (control) in the Oblast ${ }^{56}$.

For more than a year, politicians of Karaliaučius toiled in preparing the concept and the text of the Russian - EU agreement on the Kaliningrad Oblast,. By the way, residents of Kaliningrad had presented their own conception, "the region of cooperation", before the idea of the "pilot region" had been spread in the centre ${ }^{57}$. However, the Minister of Foreign Affairs of Russia, Igor Ivanov, speaking at the $9^{\text {th }}$ Session of the Council of the Baltic Sea States (CBSS) in Svetlogorsk, held March 45,2002 , stated that signing such an agreement was not expedient ${ }^{58}$.

Finally, with negotiations between Lithuania and Poland over EU membership gathering momentum and coming closer to the finish, Moscow "drew" Kaliningrad into the considerations of the so-called technical and procedural matters, especially concerning the issue of transit of Russian citizens through the territory of Lithuania to/from the Kaliningrad Oblast.

Untill the spring of 2001, Russia demanded that the EU should preserve a visa-free regime for the residents of Kaliningrad to travel to the neighbouring states. On March 6, 2001, Moscow changed its position, requesting that one-year visas be issued to the residents of Kaliningrad free of charge permitting them to enter territo-

\footnotetext{
${ }_{53}^{53}$ Lopata R., Laurinavičius M., Op. cit., p. 231; Holtom P. Op. cit., p. 45-46.

${ }_{54}^{54}$ Holtom P. Op. cit., p. 47.

${ }^{55}$ Sirutavičius V., Stanytė-Taločkienė I. Op. cit., p. 178.

${ }^{56}$ Lopata R., Laurinavičius M., Op. cit., p. 257.
} 
ries of the neighbouring states. Some weeks later they demanded that a "corridor" should be made for the residents of the home state travelling to the exclave through the neighbouring states. When the Governor of the Oblast voiced ever stronger concern that the visa regime would become the first dividing line turning the Oblast into a large reserve inside Europe, representatives of the Foreign Ministry of Russia explained that the introduction of visas would not be painful to the residents of Kaliningrad $^{59}$. The case of the so-called visa-free transit to the Kaliningrad Oblast, which was rapidly developing in 2002, clearly showed that Moscow was concerned with home state interests rather than those of the Oblast ${ }^{60}$. By the way, the federal centre did not even conceal this. In the summer of 2002 during a meeting of President Valdas Adamkus and Governor V. Jegorov in Palanga, the Lithuanian side presented a variant of the so-called magnetic identification cards, which would use modern means to ensure a smooth process for crossing the exclave - host state border. The response of the representatives of the Foreign Ministry of Russia was straightforward: "We need corridors rather than cards".

The response of the political elite of Kaliningrad should not be surprising within this context. Local politicians at the Duma of the Oblast were made to adopt resolutions demanding that the issue of transit of passengers should be related to ratification of the Agreement on the Russian - Lithuanian border at the State Duma. On the pages of newspapers or textbooks, they openly expressed disappointment that the undergoing negotiations over transit were not dealing with the deep problems of the development of the Oblast. According to the Vice Chairman of the Duma, Sergej Kozlov, this did not only increase insecurity and distrust in the federal centre, but also once again revealed tendencies allowing the identification of regional development as a quasi-colonial issue: the Oblast was the subject of the Russian Federation in which the influence of servicemen and other federal force structures dominated and in which were left no alternatives for implementing the economic, political and military interests of the home state ${ }^{61}$.

Having in mind these principles, there is little doubt that after the decisions on passenger transit had been adopted the "increased" attention shown by Moscow to the Kaliningrad Oblast in the summer of $2003^{62}$ (urging to draw up a new law on the extraordinary economic zone, a visit of Vladimir Putin to Kaliningrad and promises to get a grip on the problems of the Oblast's economic development) was nothing but attempts to ensure the further functioning of the hostage mechanism.

\footnotetext{
${ }^{57}$ Chlopeckij A., Fiodorv G., Op. cit., p. 316; Klemešev A., Kozlov S., Fiodorov G. Ostrov sotrudnichestva, Kaliningrad, 2002, s. 155-156, 162-167. Actually the name "region of co-operation" covers efforts to preserve privileges of the extraordinary economic zone, to ensure the exceptionality of the region by exactly defining the center - region relationship, to "legitimate" EU standards in the economic activity, to become the subject of the economic activity of not only the Russian Federation but also that of the European Union.

${ }^{58}$ Songal A. The Fate of the Exclave Decided. Manuscript, Kaliningrad, 2002, p. 2.

${ }^{59}$ Statement of the representative of the Ministry of Foreign Affairs of the Russian Federation to the Kaliningrad Oblast Ambassador A. Kuznecov, Baltic News Service, 26 March 2001.

${ }^{60}$ Sirutavičius V., Stanytė-Taločkienè I., Op. cit., p. 191-195.

${ }^{61}$ Gorodilov A., Kozlov S., Op. cit., s. 64.

${ }^{62}$ Stanytė-Toločkienė I. "Kaliningrado ateitis - Maskvos rankose", Lietuvos rytas, 2003 m. liepos 5 d.
} 


\section{Conclusions}

The research has confirmed the view that Moscow (the home state, the federal centre), seeking to preserve sovereignty and to ensure links with the Kaliningrad (Karaliaučius) Oblast, has turned that exclave province into a geopolitical hostage.

By specific measures of the foreign policy taken by the Kremlin, the Oblast became established in "high politics", the relations between Russia and the West, as a headache.

It is obvious that the "acuteness" of the problem depended on Moscow's ability to manipulate Russia's position by means of the external and internal factors influencing Russia's position. It should be recognised that in certain cases the home state has made use of these factors quite successfully. The West actually did not dare to refer to the complicated political and legal aspects of the status of the Kaliningrad (Karaliaučius) Oblast and most often tended to solve the political problem in technical ways. This untied the hands of the Kremlin to use pressure with respect to the neighbouring states surrounding the exclave and to make their dialogue with the Euro-Atlantic institutions more difficult. On the other hand, this paved the way for Moscow to manipulate the alleged opening of Kaliningrad (Karaliaučius) exclave to the external environment without allowing its universally recognised specificity to manifest itself in practice. However, thus far it has not been clear whether the home state will succeed in successfully maintaining the Stockholm syndrome in the exclave through this mechanism of the geopolitical hostage. 